Published in: Journal of Pragmatics Vol. 106 (2016), pp. 97-114.

POSTPRINT

\title{
A range of uses of negative epistemic constructions in German: ICH WEIß NICHT as a resource for dispreferred actions
}

Henrike Helmera, ${ }^{*} /$ Silke Reinekeb/Arnulf Deppermann ${ }^{c}$

a, b, c Institute for the German Language, Pragmatics Department, R5, 6-13, 68161 Mannheim, Germany

\begin{abstract}
Our paper deals with the use of ICH WEIB NICHT ('I don't know') in German talk-in-interaction. Pursuing an Interactional Linguistics approach, we identify different interactional uses of ICH WEIB NICHT and discuss their relationship to variation in argument structure $(\mathrm{SV}(\mathrm{O})$, (O)VS, V-only). After ICH WEIB NICHT with full complementation, speakers emphasize their lack of knowledge or display reluctance to answer. In contrast, after variants without an object complement, in contrast, speakers display uncertainty about the truth of the following proposition or about its sufficiency as an answer. Thus, while uses with both subject and object tend to close a sequence or display lack of knowledge, responses without an object, in contrast, function as a prepositioned epistemic hedge or a pragmatic marker framing the following TCU. When ICH WEIB NICHT is used in response to a statement, it indexes disagreement (independently from all complementation patterns).
\end{abstract}

Keywords: German; Interactional Linguistics; epistemics; preference organization; mental verb constructions

\section{Introduction and outline}

This paper examines turn constructional units with the negated verb nicht wissen ('to not know') in $1^{\text {st }}$ person singular present tense in German talk-in-interaction.

The basic meaning of wissen is 'to hold reliable information, based on experience or hearsay' (Duden, 2013). The negated form nicht wissen of course means the opposite: 'not to hold (reliable) information'. However, when using ICH WEIß NICHT' ('I don't know') in talk-in-interaction, speakers are not always claiming that they do not know anything about the issue in question. Building on an analysis of a large sample of occurrences of ICH WEIß NICHT, we will show that ICH WEIß NICHT can be used for a variety of actions within responsive turns: on the epistemic level, it may display different degrees of knowledge or uncertainty about the truth of an upcoming assertion; on the pragmatic level, ICH WEIß NICHT can project an insufficient answer or signal unwillingness to cooperate in the line of action that a prior speaker has projected. On the propositional level, ICH WEIß NICHT may exhibit disagreement with a prior assertion.

We will identify and discuss the following features, which affect the function of ICH WEIß NICHT:

\footnotetext{
${ }^{*}$ Corresponding author.

E-mail addresses: helmer@ids-mannheim.de (H. Helmer), reineke@ids-mannheim.de (S. Reineke), deppermann@idsmannheim.de (A. Deppermann).

${ }^{1}$ Below we use smallcaps (ICH WEIß NICHT) to refer generically to or several forms of ICH WEIß NICHT. Specific forms are indicated with italic letters, e.g. ich weiß es nicht, ich weiß nicht, weiß nicht.
} 
1) complementation pattern,

2) type of action in the prior turn, to which ICH WEIß NICHT reacts,

3) type of action that follows ICH WEIß NICHT in the same turn,

4) cooperativity of the speaker of ICH WEIß NICHT,

5) Scope of ICH WEIß NICHT,

6) semantics of ICH WEIß NICHT.

Some of these features are interdependent. As different complementation patterns are the most distinctive feature accounting for differences in use, we will focus on differences in epistemic and interactional functions of fully realized variants of ICH WEIß NICHT (with subject and object) in contrast to reduced variants (omitted subject and/or object). Since differences are not categorical, we restrict our discussion to features for which we found clear distributional patterns.

Our analysis follows an Interactional Linguistics approach. It takes into account the position of ICH WEIß NICHT within the turn as well as in the larger sequence, its grammatical form, pragmatic function, and interactional consequences of its use. With our analysis we contribute to the study of 'positionally sensitive grammar' (Schegloff, 1996), that "recognizes the fact that a wide range of utterances in everyday conversation are grammatically organized by virtue of their position in particular sequences" (Thompson et al., 2015:8).

After situating our study in the current state of research on negative epistemic constructions in other languages (Section 2), we present our data and analytic tools (Section 3). The main body of the paper presents findings on variants of the interactional use of $\mathrm{ICH}$ WEIß NICHT with different complementation patterns (Section 4). We conclude with a summary of our findings (Section 5).

\section{Prior research on negative epistemic constructions}

The relevance of epistemic verbs for marking stance in interaction has become a major topic of research in Interactional Linguistics over the last decade. The use of epistemic verb constructions as discourse markers has been shown by many researchers (e.g. Karkkäinen, 2003; Thompson, 2002; Imo 2007). While research has been conducted on several epistemic verb constructions without negation, such as / think and / mean, research on negative epistemic constructions has mainly focused on I don't know (Tsui, 1991; Scheibman, 2000; Aijmer, 2009; Weatherall, 2011) and its equivalents in other languages (cf. Keevallik, 2006, 2011, this issue, on Estonian; Lindström and Karlsson, this issue, on Swedish; Maschler, 2012, on Hebrew; Pekarek Doehler, this issue, on French; Imo, 2007 on German).

It is widely recognized that / don't know is used even when the speaker actually can and does give information (Östman, 1981; Tsui, 1991; Beach and Metzger, 1997; Kärkkäinen, 2003; Diani, 2004; Auer and Günthner, 2005; Aijmer, 2009; Weatherall, 2011). Most previous studies have pointed out that the construction has a broad spectrum of uses depending on the context (Östman, 1981; Beach and Metzger, 1997; Aijmer, 2009). I don't know has been associated with the following functions: 
- indexing tentativeness, uncertainty, doubt, or concerns (Östman, 1981; Beach and Metzger, 1997; Imo 2007; Pichler, 2007; Aijmer, 2009; Weatherall, 2011; Pekarek Doehler, this issue), mostly as an epistemic hedge or "prefatory epistemic disclaimer" (Schegloff, 1996:62), which frames an upcoming turn and indicates that speakers downgrade their commitment to the truth of the proposition;

- marking inability to answer properly (Imo 2007; Weatherall, 2011);

- displaying reluctance to answer (Beach and Metzger, 1997; Aijmer, 2009; Weatherall, 2011) and projecting non-cooperation (Keevallik, 2011);

- closing or changing a topic (Beach and Metzger 1997; Aijmer, 2009; Pekarek Doehler, this issue);

- avoiding a face-threatening act in a polite way (e.g. when speakers don't want to disagree, decline an invitation or a request, etc.; Tsui, 1991; Beach and Metzger, 1997; Pichler, 2007; Aijmer, 2009);

- for parenthetical, non-responsive uses within a multi-unit turn: as a hesitation marker or speech management signal, allowing the speaker to reflect on an upcoming utterance and gain time for planning or self-correction (Auer and Günthner, 2005; Aijmer, 2009; Pekarek Doehler, this issue).

Researchers have also analyzed differences in prosody (i.e. pitch, loudness, tempo; cf. Weatherall, 2011) and sequential position (Potter, 1997; Scheibman, 2000; Aijmer, 2009). Scheibman (2000) found a connection between morphophonetic variation and pragmatic functions: for instances of / don't know with full vowels ${ }^{2}$ in don't, she observes a literal semantics of 'not knowing'; for almost all variants with reduced vowels she finds a hedging or face-saving function and the function of signaling a speaker change. Some researchers have mentioned different positions of / don't know or ICH WEIß NICHT in multi-unit turns (Auer and Günthner, 2005; Aijmer, 2009, Pekarek Doehler, this issue). Only a few studies have dealt with the effects of different complementation patterns apart from clausal complements (Imo, 2007; Keevallik, 2011; Pekarek Doehler, this issue).

\section{Data}

Our analysis draws on the corpus FOLK of the Institute for the German Language (IDS). All transcripts $^{3}$ and aligned audio files are publicly available via <http://dgd.ids-mannheim.de>. FOLK (release 2014) comprises 101 hours of audio recordings from different interaction types, e.g. conversations between friends, parents and children, couples, meetings during shift changes in a hospital, university oral exams, and classroom interaction. We searched for all instances of nicht wissen in the $1^{\text {st }}$ person singular present tense, including all regional morphophonetic variants and all

\footnotetext{
2 By 'full vowel' Scheibman means "don't" pronounced with an [o], by 'reduced vowel' "don't" with an [ə] (cf. Scheibman, 2000:108).

${ }^{3}$ The transcriptions follow GAT2-conventions (Selting et al., 2009; Couper-Kuhlen and Barth-Weingarten, 2011; cf. Appendix).
} 
complementation patterns. The speakers in FOLK speak different types of German, from close to standard over different types of regional colloquial language to dialects. Dialectal variants as in excerpt 5 and 8 do not show systematic differences regarding our findings.

Overall, we found and analyzed N=290 instances of ICH WEIß NICHT. After an extensive single case analysis of a subset, we coded every single instance in Excel by using various categories, such as the grammatical features of ich weiß nicht, actions in the prior turn, and actions in the turns containing or following ICH WEIß NICHT.

\section{Main patterns of ich weiß nicht}

In our data, there are different morphosyntactic variants of ICH WEIß NICHT. They are distinguished by:

a) Complementation:

a. Full transitive clause with both subject and pronominal object: ich weiß es/das nicht, das weiß ich nicht ('I don't know that/it') $(\mathrm{n}=85 / 290)$;

b. Reduced variants:

- object omission: ich weiß nicht/weiß ich nicht ('I don't know') (n=155/290);

- zero complementation (=subject and object omitted): weiß nicht ('don't know') $(n=43 / 290)$.

b) Morphology: In full transitive clauses, the accusative object may be realized by the neuter pronoun es $(n=48 / 290)$ or by its demonstrative variant das $(n=37 / 290)$.

c) Word order:

a. In full transitive clauses, the pronominal object es may only follow the verb: ich weiß es nicht (SVO) ( $\mathrm{n}=48 / 290)$; the pronominal object das may either precede or follow the verb: ich weiß das nicht (SVO) ( $n=5 / 290)$ vs. das weiß ich nicht (OVS) $(n=32 / 290)$;

b. In cases of object omission, the subject may either precede or follow the verb: ich weiß nicht (SV) ( $\mathrm{n}=90 / 290)$ vs. weiß ich nicht (VS) $(\mathrm{n}=65 / 290)$.

The majority of the instances of ICH WEIß NICHT within multi-unit turns are produced as an initial TCU $(n=210 / 290)$. However, it may also be parenthetically inserted $(n=44 / 290)$ or produced as the final TCU of a multi-unit turn ( $n=36 / 290)$. Below we will only discuss turn-initial uses of ICH WEIß NICHT, because we want to present specifically the qualities of ICH WEIß NICHT that allow for the organization of sequences and following actions. Our analyses of $\mathrm{ICH}$ WEIß NICHT in parenthetical insertions or in final position within responsive turns yielded the same findings as Auer and Lindström (2015), who state: "Pre-positioned elements contextualize the speaker's contribution, while post-positioned variants recontextualize it" (2015:32). For turn-medial positions of ICH WEIß NICHT, we found that speakers use it to index approximation or exchangeability of the following item (like a number, an example, etc.; see also Pekarek Doehler, this issue; for a more detailed analysis, see Helmer and Deppermann, In Prep.). 
To sum up, in our data the constructional variants of turn-initial ICH WEIß NICHT are:

- fully realized variants:

- ich weiß es nicht $(\mathrm{n}=36 / 210,17.1 \%)$

- das weiß ich nicht $(\mathrm{n}=22 / 210,10.5 \%)$

- ich weiß das nicht $(\mathrm{n}=4 / 210,1.9 \%)$

- reduced variants:

○ weiß ich nicht $(\mathrm{n}=53 / 210,25.2 \%)$

○ ich weiß nicht $(\mathrm{n}=66 / 210,31.4 \%)$

○ weiß nicht $(\mathrm{n}=29 / 210,13.8 \%)$

In our data we found five main interactional patterns of ICH WEIß NICHT, which seem to correlate with the complementation patterns of ICH WEIß NICHT (4.1 lists tendencies of full verb complementation, and 4.2 lists tendencies with reduced verb complementation). Speakers may use ICH WEIß NICHT as a fully responsive stand-alone turn when they do not subsequently contribute to the topic (4.1.1). However, turns beginning with ICH WEIß NICHT are frequently expanded. The expansions reflexively index and clarify semantic, epistemic, and pragmatic aspects of the situated meaning of ICH WEIß NICHT. Besides emphasizing or explaining their lack of knowledge and thus rejecting epistemic authority (4.1.2), speakers may display their reluctance to cooperate, claiming the irrelevance of a question or refusing to respond (4.1.3). In the majority of cases though, speakers expand the topic in the further course of an interaction by communicating some sort of knowledge that might help the other speaker(s) solve the relevant issue (4.2.1 and 4.2.2). The fifth pattern differs in its sequential, semantic, and pragmatic features: by reacting with ICH WEIß NICHT to a statement, assessment, etc. of other speakers, speakers perform a disaffiliative, disagreement turn (4.3).

As stated above and as can be seen from Table 1, the different interactional uses of the 210 turn-initial instances of ICH WEIß NICHT tend to be associated with different complementation patterns. ${ }^{4}$ Speakers are more likely to use ICH WEIß NICHT with full complementation as a fully responsive turn that projects no further contribution to the topic, or to display lack of knowledge or reluctance to cooperate. Displays of knowledge are more frequently linked to reduced patterns of ICH WEIß NICHT. 'Reduced variants' include both variants with a subject but no object (ich weiß nicht, weiß ich nicht) as well as those without an object or subject (weiß nicht).

\begin{tabular}{|l|l|l|l|}
\hline & $\begin{array}{l}\text { Fully realized } \\
\text { variants }\end{array}$ & $\begin{array}{l}\text { Reduced } \\
\text { variants }\end{array}$ & $\begin{array}{l}\text { Overall } \\
\text { frequency }\end{array}$ \\
\hline 1) No further contribution by the same speaker & $20\left(32.3 \%{ }^{5}\right)$ & $42(28.4 \%)$ & $62(29.5 \%)$ \\
\hline
\end{tabular}

\footnotetext{
4 This does not hold for the fifth pattern, the disaffiliative use, which is contingent on the nature of the prior turn.

5 Percentages refer to the relative frequency of the specific cell with respect to the overall number of the same complementation pattern. In this case the percentage means 'in $32.3 \%$ of the 62 cases with fully realized forms, there is no further contribution to the topic by the same speaker after the TCU with ICH WEIß NICHT (=das weiß ich nicht, ich weiß das nicht, ich weiß es nicht)'.
} 


\begin{tabular}{|l|r|r|r|}
\hline 2) Display of lack of knowledge & $9(14.5 \%)$ & $7(4.7 \%)$ & $16(7.6 \%)$ \\
\hline 3) Display of the question's irrelevance & $6(9.7 \%)$ & $5(3.4 \%)$ & $11(5.2 \%)$ \\
\hline 4$)$ Display of knowledge & $23(37.1 \%)$ & $82(55.4 \%)$ & $105(50 \%)$ \\
\hline 5) Objection & $3(4.8 \%)$ & $6(4.1 \%)$ & $9(4.3 \%)$ \\
\hline Uninterpretable 6 & $1(1.6 \%)$ & $6(4.1 \%)$ & $7(3.3 \%)$ \\
\hline Total token frequency & $62(100 \%)$ & $148(100 \%)$ & 210 \\
\hline
\end{tabular}

Table 1: Frequencies of the five interactional patterns of ICH WEIß NICHT

\subsection{Tendencies of ICH WEIß NICHT with full complementation pattern}

We observed three patterns that occur more frequently with full complementation patterns of ICH WEIß $\mathrm{NICHT}$ than with its reduced variants. Almost all7 of the interactional uses discussed in this section (4.1) are used to perform dispreferred responses to (epistemic) wh-questions or polar interrogatives, i.e. responses which do not fulfill the pragmatic expectation of being a sufficient answer to a prior speaker's question. Frequently speakers do not contribute anything other than ICH WEIß NICHT to a topic that another speaker has initiated with a question (4.1.1). Following speakers usually treat it as a sufficient response; they insist on an answer only very rarely in particular cases. If speakers expand their turn beyond ICH WEIß NICHT, they either show that they are not able to contribute something else (4.1.2), or they display that they are not willing to deal with the question (4.1.3). Only in the latter cases do speakers not only give dispreferred responses, but even behave uncooperatively, in the sense that they do not want to give a conditionally relevant answer at all. ${ }^{8}$

ICH WEIß NICHT with full complementation always seems to have retrospective scope, which may arise from the fact that the object pronouns das and es are interpreted as anaphorically co-referential with the question raised in the prior turn. The first three patterns are associated with full verb complementation, rather than with reduced complementation.

\subsubsection{Pattern 1: No further contribution to the topic by the same speaker}

Participants frequently close a topic with ICH WEIß NICHT: in 62 instances (see row 1 in Table 1) speakers do not display any knowledge and do not comment on the topic further, whether by expanding the turn or whether later on, even when other speakers continue to contribute to the topic.

\footnotetext{
${ }^{6}$ Speakers' turns are incomprehensible or incomplete; cut-offs usually occur due to overlap.

7 The exception is the use of ICH WEIß NICHT in combination with auch (ich weiß es auch nicht, etc., see Excerpt 2). In these cases the TCU usually signals affiliation to the prior speaker.

${ }^{8}$ We can see from Pattern 1 (4.1.1) that even no-knowledge responses are treated as conditionally relevant and sufficient responses, even if they are dispreferred with regard to content.
} 
Excerpt 1 is an instance of a single-unit turn. Seven friends are playing a soccer manager game, in which they recruit an imaginary team by bidding for players. Before the excerpt the friends are bidding for the soccer player Marcello Bordon.

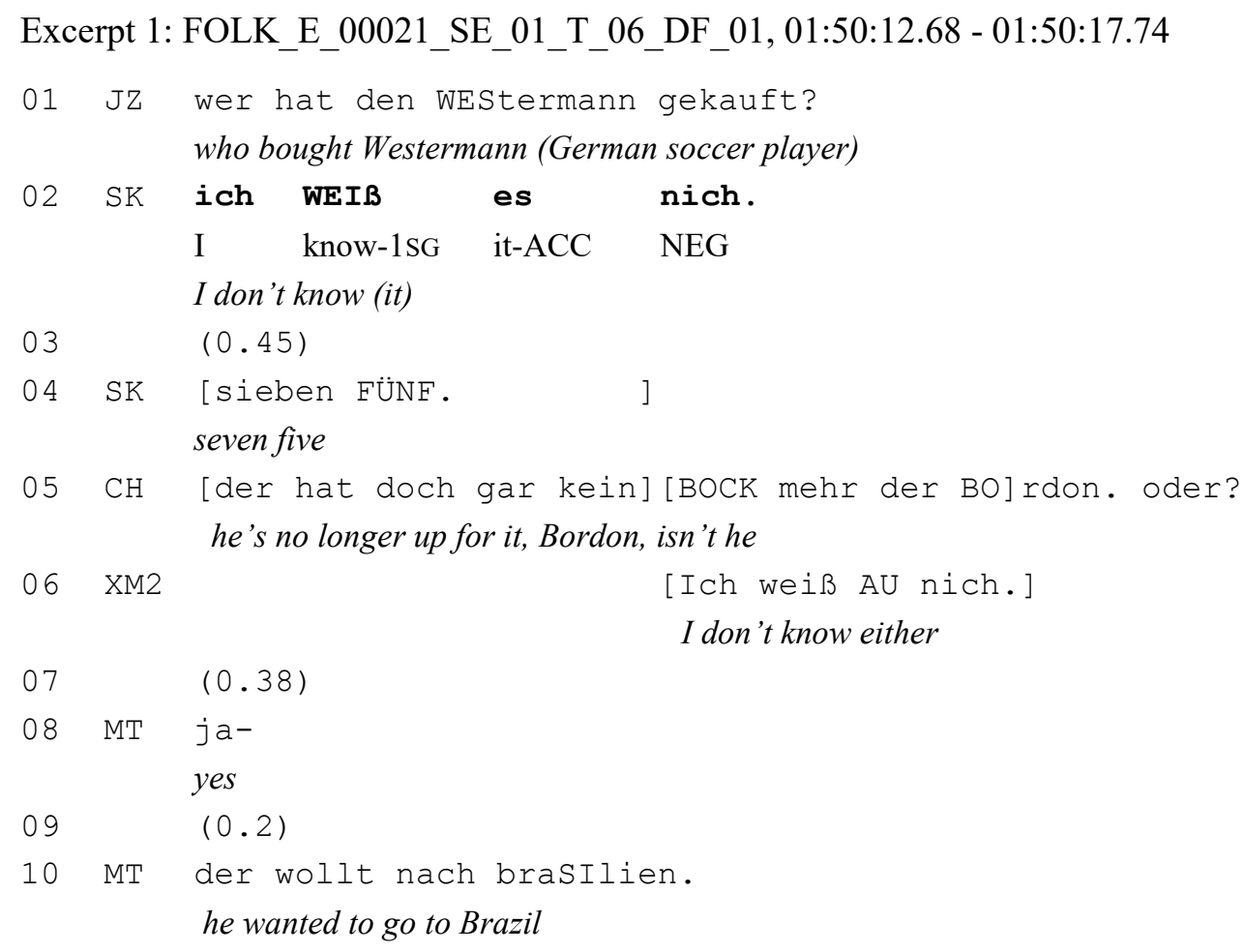

During the bidding sequence, JZ asks who had previously bought the soccer player Heiko Westermann (line 01). With this wh-question he initiates a joint project to clarify who has Westermann on his team. As a second-pair part, SK reacts with the answer "ich WEIß es nich." ('I don't know it.', line 02), marking this as a full answer with falling intonation at the end. He then changes the topic by repeating his bid for the current player ("sieben FÜNF", 'seven five', line 04), while $\mathrm{CH}$ talks about Marcello Bordon (line 05). After another speaker claims to have no knowledge as well (line 06), the sequence about Westermann is closed and the friends continue to talk about Marcello Bordon (lines 08-10).

In cases like this, ICH WEIß NICHT follows as a response to a question asked by a prior speaker. Speakers use ICH WEIß NICHT to display that they are not able to answer the question or to contribute to the issue in question. The turn is clearly dispreferred in terms of the relevant type of response, but it is not structurally modified apart from occasional closed class items (see below) that display awareness of the dispreferred status. ${ }^{9}$

The fully realized and reduced forms in this pattern occur with only slightly different frequencies $(32.3 \%$ vs. $28.4 \%$, respectively). The word order of the reduced forms, however, reveals some

\footnotetext{
${ }^{9}$ Dispreferred responses in the sense of frustrating an expectation of the prior speaker may, but do not have to be, structurally marked (see Bilmes, 1988 on different concepts of preference).
} 
differences among them: those with 'verb-subject' word order that drop the object initially ([ø] weiß ich nicht) are very similar to cases with fully realized complement patterns. Their scope is retrospective and they are used as a fully responsive single-unit turn more frequently than the SV- and V-onlyvariants (ich weiß nicht and weiß nicht). $37.7 \%$ of weiß ich nicht-variants constitute this first interactional pattern, whereas this is the case only for $23.2 \%$ of the other reduced complementation patterns (ich weiß nicht and weiß nicht). ${ }^{10}$ That is, the high percentage of reduced variants in Table 1 , row 1 , is caused by the reduced VS-variants.

Speakers frequently $(n=58 / 210)$ use closed class items as modifiers. In our data these are mostly TCUs with full complementation patterns and they frequently occur when speakers don't contribute anything else to the topic. In $40.3 \%(n=25 / 62)$ of the cases with full SVO/OVS complementation patterns (ich weiß das/es nicht, das weiß ich nicht), modifiers are included in the TCU, whereas this is the case for only $22.3 \%(n=33 / 148)$ of the instances with reduced complementation patterns (without an object complement or with no complement). In most of the cases in which speakers use closed class items as modifiers:

- speakers align themselves with the epistemic status of prior speakers, using additive connectives like auch ('either', $n=18 / 58$ ),

- speakers mitigate their claim of lack of knowledge:

- concerning a temporal scope, i.e. they convey that they don't know the answer now, but knew it before, using temporal adverbs like jetzt ('now) or mehr ('anymore') ( $n=15 / 58$ ), or that they will or might know it in the future, using temporal adverbs like noch ('still', n=5/58),

- concerning the degree of accuracy or their commitment to the knowledge stated, using grading devices (like genau, 'exactly'), and conveying that they basically know but are not sure if they know the issue in question well enough for current purposes (ich weiß nicht ganz genau ('I don't know exactly'), $n=4 / 58$ ),

- speakers use modal particles and adverbs, like wirklich ('really'), gar, echt ('absolutely'), to emphasize lack of knowledge $(n=4 / 58)$.

Apart from TCUs with auch, which signal alignment with the lack of knowledge of another speaker and which exhibit a preferred status, modifiers usually index some sort of account for the lack of knowledge. Speakers communicate that they are sorry for not knowing, that they are aware that they should know, or that they knew before. Accounts implicitly address the frustration of the other speaker's expectation that the speaker of the ICH WEIB NICHT-turn had epistemic authority (Heritage and Raymond, 2005), which is particularly relevant when answering questions. Thus, modifiers added

\footnotetext{
${ }^{10}$ For a more detailed analysis that also considers the word order of reduced variants, see Helmer, Deppermann, and Reineke (In Prep.).
} 
to ICH WEIß NICHT provide evidence for the dispreferred status of the response turn (cf. Pomerantz, 1984).

\subsubsection{Pattern 2: Display of the lack of knowledge}

In other cases, speakers continue their ICH WEIß NICHT-TCU. Sometimes they emphasize their lack of knowledge, stressing that they cannot contribute to solving the issue in question. They usually do this after uttering a fully realized ich weiß es/das nicht, das weiß ich nicht (14.5\% of fully realized variants vs. $4.7 \%$ of reduced variants; see row 2 in Table 1). Speakers may additionally explain their lack of knowledge or provide evidence for it, like in Excerpt 2 from a biographic interview. The interviewer MF asks a pupil (STP4) about his plans for the future. When STP4 says he can imagine playing the trumpet in an orchestra, they discuss whether this idea is realistic or not.

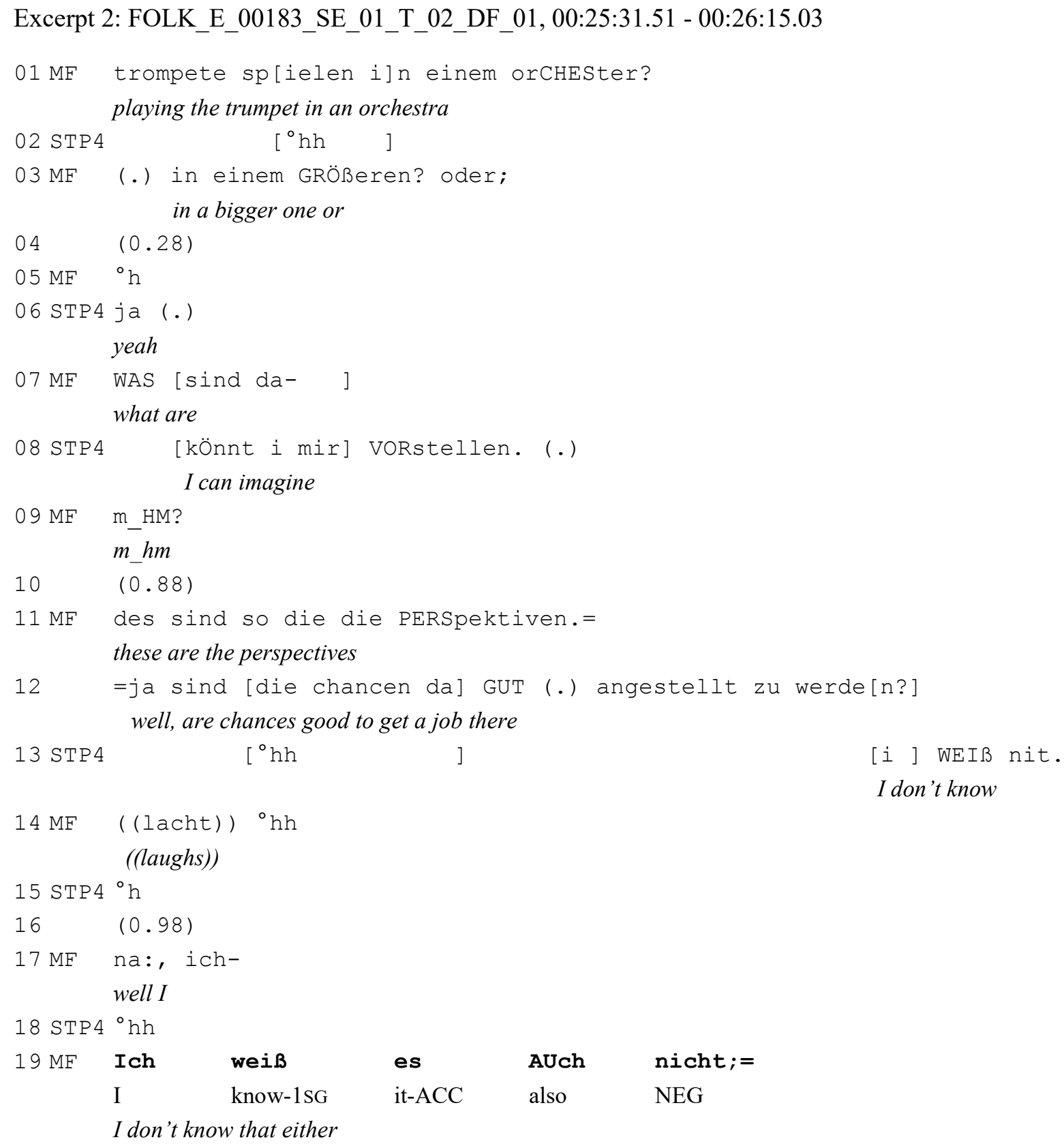


well, I am pretty untalented and ignorant in this field

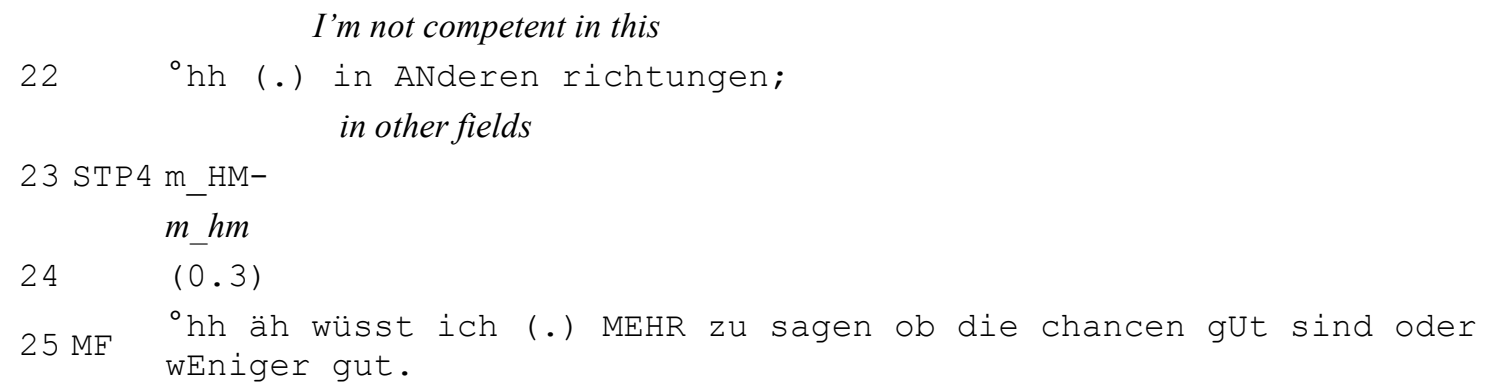

After MF asks if STP4 will have good prospects to play in an orchestra (lines 11-12), STP4 claims not to know (line 13), which is a closure-implicative negative response in reaction to the first-pair part. MF treats this as a claim of lack of knowledge and after he laughs (line 14) he claims in response, "na:, ich- ich weiß es AUCH nicht;" ('I don't know that either', lines 17/19), stressing his own lack of knowledge with "AUCH" ('either'). With this he signals affiliation with the student. MF doesn't conclude the topic by showing his disaffiliation, but marks that he might continue with pitch that falls to mid (instead of low) at the end of the intonation phrase, that he might continue. He then instantly repeats his lack of knowledge by claiming that he is both untalented and ignorant regarding the matter (lines 20-21), thus ruling out that his response might be understood as indexing a negative assessment of the student's plans (cf. 4.2.3).

In cases like this, speakers emphasize their lack of knowledge, sometimes providing an account (see also Pekarek Doehler, this issue) and displaying that they are acting cooperatively, in the sense that they give an account for their lack of knowledge and do not decline a joint project, although they may not be able to contribute relevant knowledge.

In contrast to Pattern 1, speakers who produce ICH WEIß NICHT in Pattern 2 seem to feel the need to give an account for their no-knowledge response. This may have to do with the participation framework: 12 in each of the 22 cases (with both full and reduced complementation patterns, see Table 1, row 2), speakers are either participants in dyadic interactions or are directly and clearly addressed by name, or in some other way, in multi-party-interactions. Having been directly addressed, a speaker producing a single-unit ICH WEIß NICHT, like in Pattern 1, may not always suffice. However, this does not imply that elaborating on a no-knowledge response is necessary; we also find several single-unit instances of ICH WEIß NICHT (Pattern 1) in dyadic interactions.

\footnotetext{
11 In this and the following transcripts, we use underlining to indicate utterances (by the same speaker) after ICH WEIß NICHT which refer to the speaker's knowledge/epistemic status or which contribute to the issue in question with regard to content. 12 We thank one of the anonymous reviewers for this remark regarding the participation framework (dyadic/multi-party) in our examples.
} 


\subsubsection{Pattern 3: Display of the question's/issue's irrelevance}

When closing the topic or stressing their lack of knowledge, speakers might give dispreferred responses (sometimes the response might even signal preference and affiliation, like in Excerpt 2), but in any case they behave cooperatively at least in a formal way, i.e. they give a (no-knowledge) response to the question and possibly even an account for not knowing. This is different for Pattern 3 , as we will see from Excerpt 3, taken from an interaction between a father (VK) and his two daughters (only one daughter, SK, appears in the transcript) playing the game Monopoly:

Excerpt 3: FOLK_E_00011_SE_01_T_02_DF_01, 00:30:56.69 - 00:31:16.14

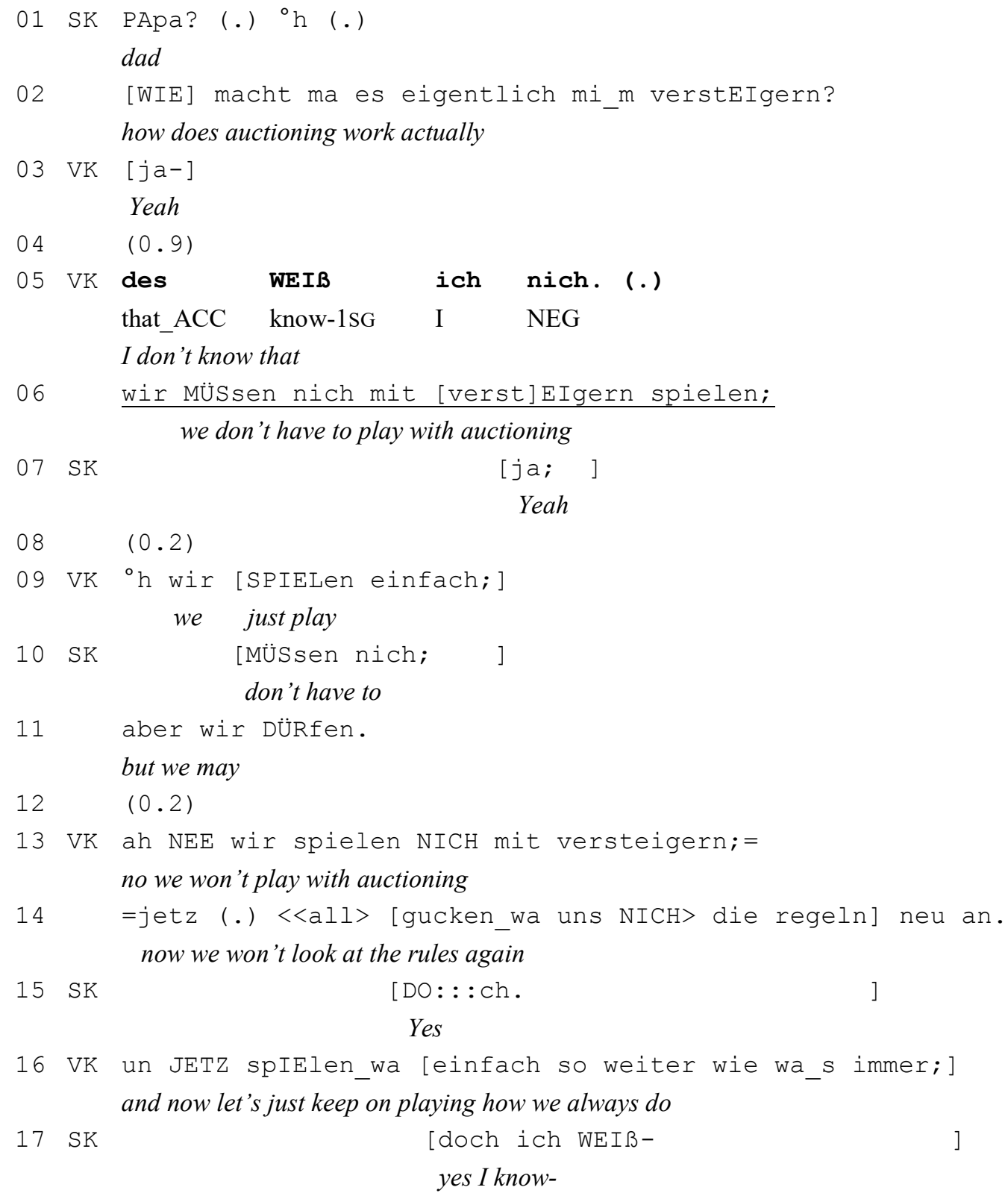

The daughter SK wants to know how auctioning works in the game (lines 01-02). Her wh-question makes an answer conditionally relevant. It is not clear, however, if SK just wants to know about this 
option or if she actually wants to integrate it into the current game. As an answer in second position, VK says "des WEIß ich nich." (line 05), i.e. he claims lack of knowledge and thus inability to answer the question. Given the pitch falling to low at the end of the intonation phrase and the micropause after the TCU, "des WEIßich nich. (.)" could suffice as a response to SK's question (cf. 4.2.1). However, after a micropause he downgrades the relevance of the question by saying "wir MÜSsen nich mit verstElgern spielen;" ('we don't have to play with auctioning', line 06), which can be understood as a pre-rejection to collaborate in the joint project that SK may have projected by her question. As the daughter objects in overlap to another utterance (lines 09-11), VK makes his rejection explicit by announcing that they will not play with that option and that they will not look at the rules of the game to find out how it works (lines 13-14). The father thus not only claims lack of knowledge and the irrelevance of the question, but also displays reluctance to cooperate in the joint project SK has proposed and refuses to acquire the necessary knowledge. He closes the negotiation with the decision that they will keep on playing like they always do (line 16).

In contrast to all other patterns, in these instances speakers not only give a dispreferred response, but also behave overtly in an uncooperative fashion, showing that they do not want to deal with the topic or in a joint project initiated with a prior speaker. Reasons for that can only be deduced, but may include a lack of time or an awareness that an answer would be even more dispreferred than claiming not to know. In these cases, speakers not only disalign "with the activity by not providing the action that is due" (Stivers, 2008:52), but they also display reluctance or communicate that discussing, answering, or thinking about the issue in question is not relevant now. They do this more frequently after uttering a fully realized ICH WEIß NICHT than after reduced variants $(9.7 \%$ vs. $3.4 \%$; see row 3 in Table 1).

\subsection{Pattern 4: ICH WEIB NICHT with reduced verb complementation - Display of knowledge}

While Patterns 1-3 are more often used with full complementation patterns of ICH WEIß NICHT, speakers use Pattern 4 most of all, and with reduced variants more often than with fully realized variants. As can be seen from row 4 in Table 1, Pattern 4 is also a frequent usage for full complementation patterns of ICH WEIß NICHT (37.1\%), but it is used with reduced variants much more frequently (55.4\%). Therefore we speak of the tendency of this interaction pattern to be used with reduced variants.

Using ICH WEIß NICHT without an object (and sometimes also without a subject), speakers mostly expand their turn with a cooperative contribution. They often add a display of some sort of knowledge or even provide what seems to be a full answer to the question. ICH WEIß NICHT in these cases emerges either as an epistemic hedge (cf. 4.2.1) or as a pragmatic marker (cf. 4.2.2). Depending on its usage, the meaning of ICH WEIß NICHT differs slightly: used as an epistemic hedge, nicht wissen means 'not knowing about the truth of a proposition', i.e. speakers display uncertainty about the truth of the following utterance. Used as a pragmatic marker, nicht wissen refers to the sufficiency of a proposition, i.e. speakers display that they might even be certain about the truth of the following 
utterance, but indicate that it might not be sufficient (as an answer) or optimal (as a proposal, etc.). However, both usages are very similar regarding their sequential, grammatical, and pragmatic features and are therefore considered variants of one main pattern here.

\subsubsection{ICH WEIß NICHT as an epistemic hedge}

Speakers who do not have certain knowledge sometimes produce a guess after turn-initial ICH WEIß $\mathrm{NICHT}$, thereby cooperating in the joint project proposed by the prior speaker. In these cases ICH WEIß NICHT clearly has an epistemic meaning.

In Excerpt 4, an interviewer (NL) asks a pupil (SMA3) about her and her classmates' opinions about dialects. After talking in general about making fun of dialects, NL is interested in which specific dialects are used for this:

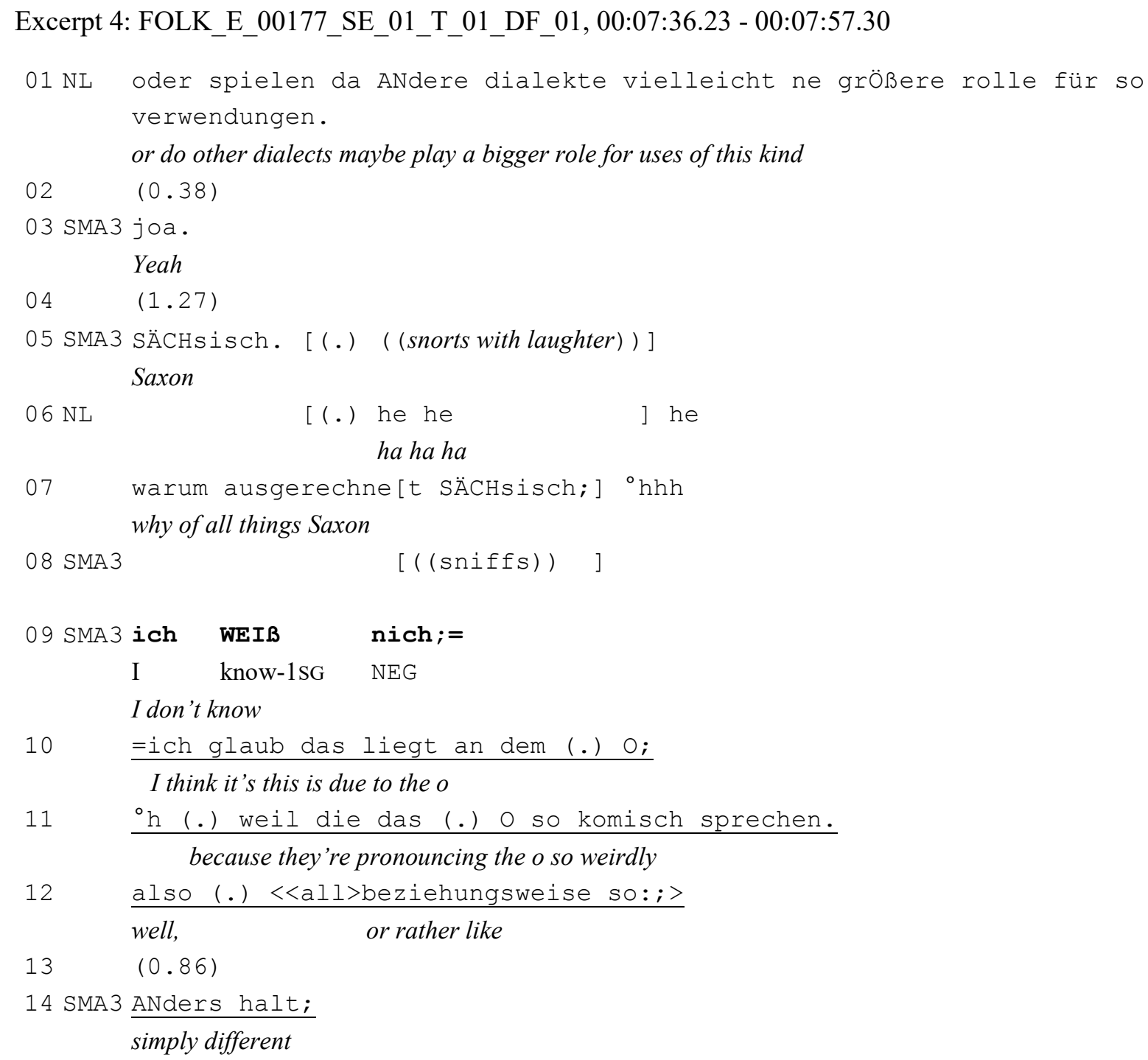

After NL asks SMA3 about specific dialects that she and her fellow pupils make fun of (line 01), SMA3 names the Saxon dialect (lines 02-05). NL asks SMA3 why her classmates specifically ridicule the 
Saxon dialect. With this first-pair part he initiates a new joint project and wants to specifically talk about features of this dialect. At first SMA3 claims not to know (line 09), but instantly makes a guess: Saxons have a specific manner of pronouncing the /o/ (line 10), which is considered to be funny, weird, or at least different by members of other speech communities (lines 11-14).

By prefacing her answer with "ich WEIß nich;" (line 09), the pupil indexes reduced certainty and frames the following assertion as a guess, but not an answer that the interviewer should take as certain knowledge. "ich WEIß nich;" here is used as a preliminary epistemic hedge (Weatherall, 2011) or a prefatory epistemic disclaimer (Schegloff, 1996) that indexes uncertainty and tentativeness. This resonates with the fact that statements following ICH WEIß NICHT often contain other epistemic hedges such as ich glaub ('I think', line 10), vielleicht ('perhaps'), etc. (cf. Aijmer, 2009:157).

Making guesses despite a low epistemic status may index being cooperative by trying to contribute to a joint project, although no certain knowledge is available. In such cases, the TCUs after ICH WEIß $\mathrm{NICHT}$ as an epistemic hedge are treated as a tentative answer to the prior question, so the scope of ICH WEIß NICHT itself should not be considered to be retrospective ('I don't know the answer to question $X$ '). Instead, the scope seems to be prospective ('I don't know if the following proposition $Y$ is true, but I consider it as a possible answer to question $\left.X^{\prime}\right)$.

\subsubsection{ICH WEIß NICHT as a pragmatic marker}

In other instances, speakers produce ICH WEIß NICHT after a question, but then display that they have some (partial or related) knowledge or proposals to solve the issue in question.

In these cases, ICH WEIB NICHT is a pragmatic marker rather than an epistemic marker because it prefaces utterances that may express certain knowledge, but which speakers mark as dispreferred responses, as they do not consider them sufficient answers to the question. The subsequent utterances can be displays of partial or related knowledge, tentative (but not obligatory) proposals, or even full answers.

Excerpt 5, from another interview, shows an instance in which a speaker may not be able to answer a question exhaustively or adequately, but gives exemplary information that allows the prior speaker to construct a possibly sufficient and exhaustive answer by himself. Before the excerpt the interviewer (NL) had asked the pupil (EST4) about his activities in an orchestra, the pupil had said that there are too few young musicians joining the orchestra, and the interviewer had asked why.

Excerpt 5: FOLK_E_00186_SE_01_T_02_DF_01, 00:19:16- 00:19:39

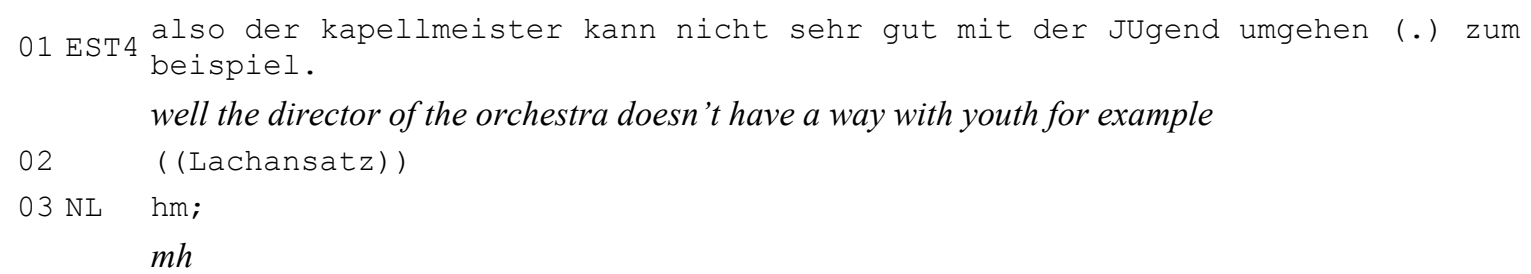




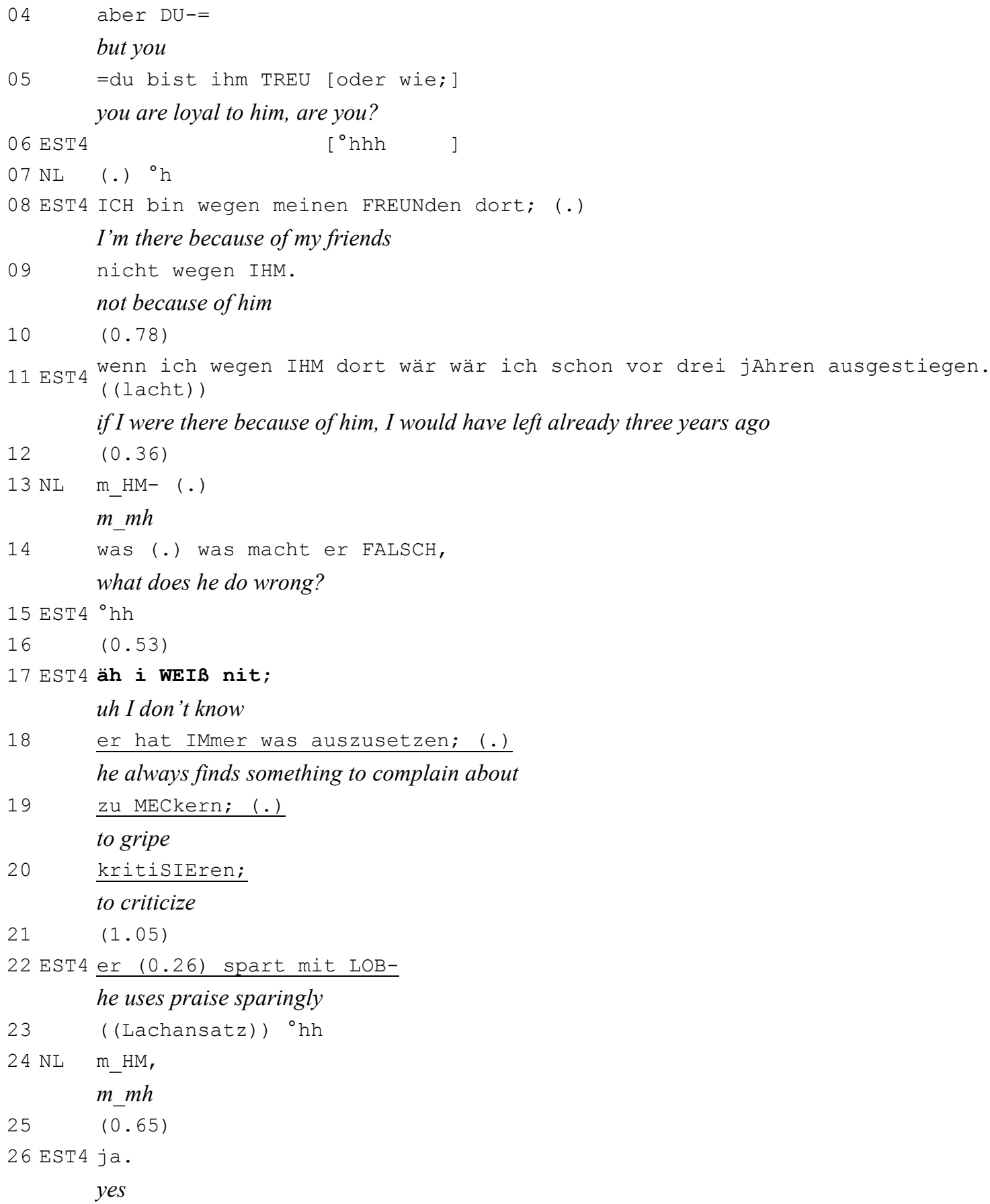

After the interviewer asks why it is hard to recruit young musicians into the orchestra, the pupil claims that the director does not treat young people properly (line 01). The interviewer asks if the pupil himself is loyal to the director (lines 04-05), which is negated by the pupil, who stresses that the only reason he is still part of the orchestra is because of his friends and that otherwise he would have left already years ago (lines 08-11). The interviewer then asks what the director does wrong (line 14). This question makes an answer conditionally relevant, and the pupil responds "äh i WEIß nit;" ("uh I don't know', line 17). Then, he directly expands his response and lists four examples of what the director does wrong. The first three examples are alternative formulations for the same or similar actions: the director continually complains (line 18), gripes (line 19), and criticizes (line 20). The fourth example describes the lack of a desirable action: the director uses praise sparingly (line 22). With this list, the 
pupil gives several examples of actions that fit the vague concept of 'doing wrong' (that was evoked by the interviewer in line 14). His "i WEIß nit;" does not downgrade his certainty about the truth of the subsequent propositions. However, with the alternative formulations and hesitation markers (pauses in lines 18-22) he displays that he is aware of the fact that these examples may not be sufficient responses to the interviewer's question, even though the examples contribute to the concept in question.

Another example of ICH WEIß NICHT as a pragmatic marker is Excerpt 6. It is from the same interaction as Excerpt 3 , in which a father is playing Monopoly with his daughters.

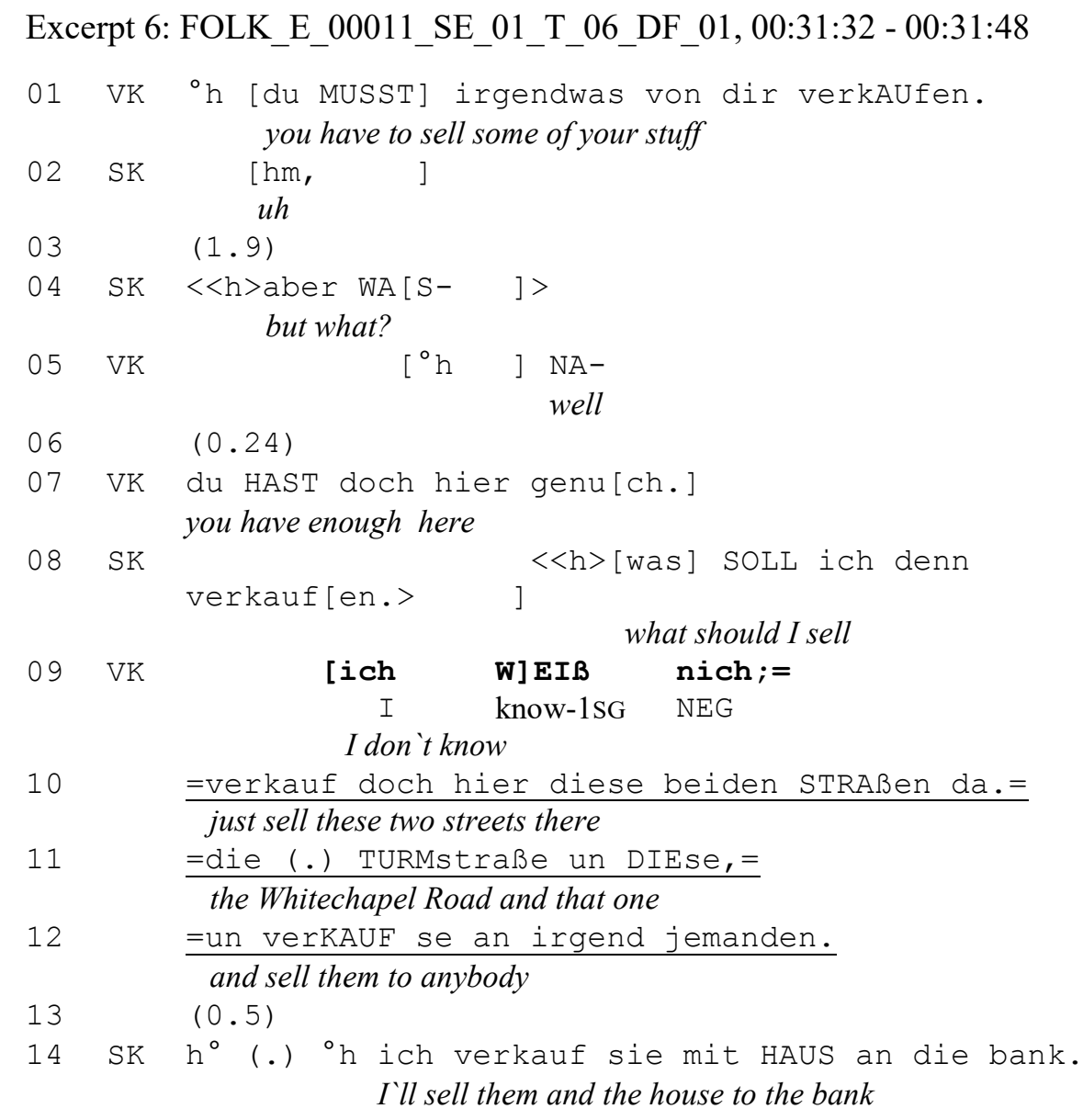

After VK tells SK that she has to sell something (line 01) before she can proceed in the game, SK asks him what she should sell (line 04). VK first rejects this request to tell her what to sell by claiming that she has enough to sell (line 07 ). SK insists by repeating her first-pair part more explicitly "was SOLL ich denn verkaufen." ('what should I sell', line 08), which makes a proper response locally relevant. After VK utters that he does not know (line 09), he immediately makes a proposal (lines 10-12), to which SK agrees in the end (line 14). The ICH WEIß NICHT-TCU indicates that the upcoming proposal is not based on a certain belief that this is the one and only (right) way to solve the situation (as, like VK claims, SK has "enough" other items to sell, line 7). Although the action following ICH WEIß NICHT constitutes an answer to the prior question and so the whole turn could be viewed as having a 
retrospective scope, the scope of $I C H$ WEIß NICHT itself seems to be prospective rather than retrospective here.

In cases like Excerpts 5 and 6, ICH WEIß NICHT is not used as an epistemic hedge, but as a pragmatic marker. It does not operate on an epistemic level, but on speech acts (see Sweetser, 1990). Moreover, as Fraser has stated, "pragmatic markers are not part of the propositional content of the sentence" (Fraser, 1996:169); they "have procedural meaning and specify how the sentence of which they are a part is related to the preceding discourse" (Fraser 1996:170). In our data, ICH WEIß NICHT used as a pragmatic marker is used to show that speakers cannot answer a question as completely or with as much detail as the questioner might expect. Alternatively, it indexes that a proposal or suggestion is only an option, but not obligatory.

We observed a tendency concerning the relationship between the complementation patterns of $\mathrm{ICH}$ WEIB NICHT and speakers' displays of knowledge in the further course of the interactions. After full complementation of ICH WEIß NICHT, speakers later display knowledge or behave cooperatively in only $37.1 \%$ of all instances of fully realized variants. Having produced a reduced variant of ICH WEIB NICHT, however, speakers display knowledge in $55.4 \%$ of all instances of reduced variants. An explanation for this difference may be that speakers use ICH WEIß NICHT in full complementation patterns to co-refer anaphorically to prior talk, whereas they frequently use ICH WEIß NICHT with reduced complementation to project an upcoming assertion.

\subsection{Pattern 5: Objection}

In contrast to the previous patterns, the fifth pattern is used the same percentage of the time with full complementation and with reduced variants of ICH WEIß NICHT (see row 5 in Table 1). Moreover, this pattern also differs from the others in another regard: speakers use it in a specific sequential context (cf. Schegloff, 1996 on "positionally sensitive grammar"), i.e. never after questions, but only after statements. With every other pattern the local function of ICH WEIß NICHT cannot be definitively determined upon its production; we can observe tendencies, but the actual function does not become clear until the speakers finish their turn (Pattern 1) or only becomes clear by virtue of the continuation of their turn (Pattern 2, 3 and 4). In contrast, when ICH WEIß NICHT is produced in response to a statement, an assessment, or a rhetorical question, it is immediately clear that the speaker's ICH WEIß NICHT indexes a disagreement with the prior (pro)position. ICH WEIß NICHT may be used as a single-unit turn which performs the disagreement itself. The turn can also be expanded to make the disagreement or the speaker's motivations or doubts explicit, but in these cases ICH WEIB NICHT is neither an epistemic hedge nor a pragmatic marker; rather, it performs the stance-taking action by itself.

Whereas sometimes responses are clearly other-initiated (e.g. after evaluative questions), in other cases (like after assessments) responses are only optional; in such cases it is not easy to say whether 
they are other- or self-initiated (cf. Stivers and Rossano, 201013). A self-initiated response with ICH WEIß NICHT that follows an assertion is shown in Excerpt 7. Two students are discussing whether a professional career is compatible with having children:

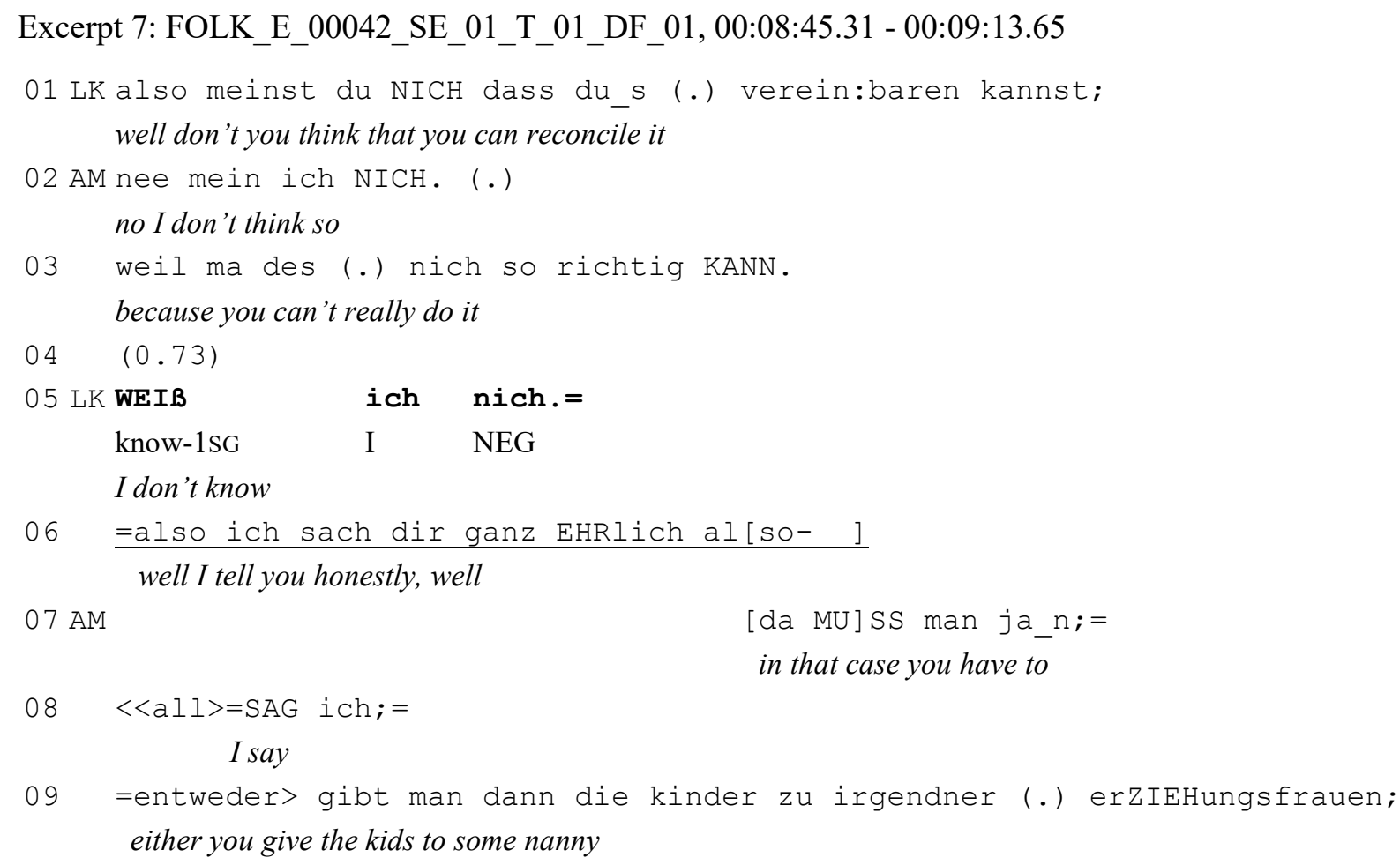

Before the excerpt, AM has claimed that it is impossible to pursue a professional career and have children at the same time. LK asks whether she really believes this (line 01, which may be taken as a pre-disagreement) and AM confirms (lines 02-03). Her statement in line 03 does not provide any new information and is designed to close the sequence. Nevertheless LK reacts with a disaffiliative turn prefaced by "WEIß ich nich." (line 05). He projects an objection with "also" and "ich sach dir ganz EHRlich" ('well I tell you honestly', line 06), which clearly marks his disaffiliation. AM interrupts and gives a reason for her opinion (lines 07-09). In the following turns the topic is shifted and they talk about the (im)possibility of leaving the kids with a husband who stays at home.

Due to the interruption, LK cannot elaborate his first disaffiliation after ICH WEIB NICHT. However, in other cases speakers support their disagreement in subsequent turns. They make explicit that ICH WEIß $\mathrm{NICHT}$ is expressing doubt and why it is doing so, like in Excerpt 8, taken from a meeting at a social organization for children with behavioral disorders and from adverse familiar conditions. The staff is talking about a mother who usually gives in to her child's requests:

Excerpt 8: FOLK_E_00022_SE_01_T_03_DF_01, 01:34:47.19 - 01:35:56.81

$01 \mathrm{AW}$ also ich mein man mUss es sich VoRstellen; =

13 The authors show that first assessments do not necessarily project second assessments (Stivers and Rossano 2010:9ff.). 
well I mean you have to imagine

02 =er schweigt sie die ganze zeit nur $\mathrm{AN},=$ he says nothing to her all the time

03 =und dann redet er EIN mal und sagtand then he talks once and says

04 ((breathes in for 1.24 sec.))

05 (.) ich möchte !SO! gerne mit der verein_a <<dim>dann zu dem fAstnachtsumzug.>

I'd love to go to the carnival procession with the association_a

$06 \quad(0.59)$

07 AW des (.) diesen braten (.) !RIECHT! ma (.) zEhn meter gegen den WIND; you can smell that rat ten meters off

08 BS (.) hm.

$h m$

$09 \quad(1.0)$

10 AW aber sie WILL ihn net riechen?

but she doesn't want to smell it

$11 \quad(1.54)$

12 AW und kippt an_ner stElle um wo se einfach vielleisch ma hätte NET (.) umkippen sollen; $=$

and gives in at a point where maybe she simply should have not given in

13 =nUr weil er mal REdet;

only because he talks for once

$14 \quad(0.86)$

15 AW des mAcht misch [ganz des ver] wirrt mich SEHR. that really makes me completely, that really puzzles me

$16 \mathrm{SZ}$

[mh: : , ]

m_hm

$17 \mathrm{SZ}^{\circ} \mathrm{h}$ ja aber ich WEIß net.

yes but Inow-1SG NEG

yes but I don't know

18 ich GLAUB,

I think

$19 \quad(0.37)$

20 SZ äh (.) ich MEIN-

uh I mean

21 (1.07)

22 sz die die $\mathrm{k}$ die $\mathrm{k}$ die KENNT den ja schon auch ganz gut.=

she she she she knows him quite well actually, too

23 und ich mein SIE [isch ja schon] auch f ((Lachansatz)) FROH? ${ }^{\circ} \mathrm{h}$

and I mean she actually also is ((begins to laugh)) pleased

24 AW [ja KLAR. ]

yeah sure

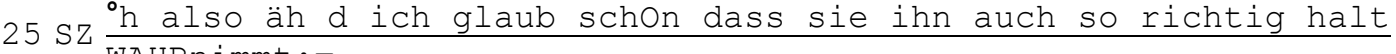

WAHRnimmt ;

well I actually do think that she perceives him like properly

$26 \mathrm{SZ}=$ und a da AUFmerksam isch;

and that she is attentive in this regard

$27 \mathrm{SZ}=$ und $^{\circ} \mathrm{h}$ sie isch ja schon einfach auch $\mathrm{EROH}$ ähm; 


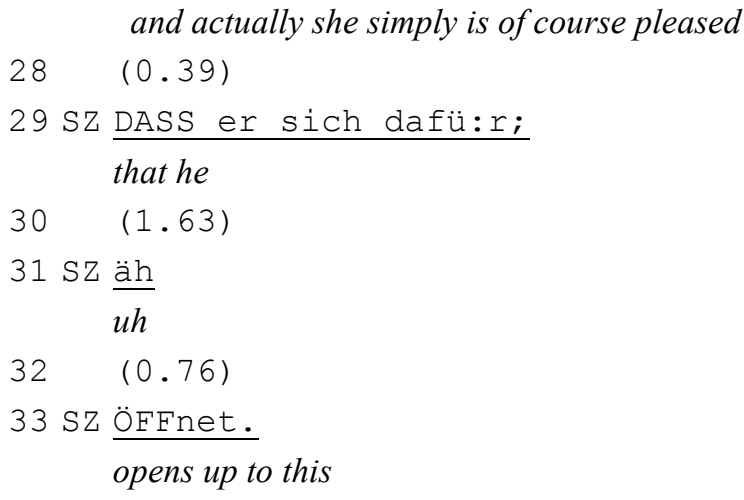

AW considers the boy's wish to participate in the carnival procession as a way of avoiding the physical education courses he should take. She accuses the mother of feigning not to notice this. AW's comment(s) (lines 01-15) make a reaction relevant. After a delayed turn start that projects a dispreferred response, SZ disagrees with "ja aber ich WEIß net ${ }^{14}$." (line 17) and adds evidence for her doubt: "die KENNT den ja schon auch ganz gut." (line 22: 'she knows him quite well actually, too'). Then she elaborates her doubt (lines 23ff.): she believes that the mother is quite perceptive and attentive regarding her son, i.e. that she can tell if a request is honest or just an excuse. The "ja aber" ('yes but') (line 17) already projects a concessive move, so it is not possible to attribute the function of disagreement only to "ich WEIß net." However, in many disaffiliative cases ICH WEIß NICHT is initiated with other items that (can) mark objections, like ja aber, also ('well') or hesitation markers. Those items, including ICH WEIß NICHT, are optionally co-occurring markers of dispreference and disaffiliation.

The evidence that speakers provide to refute other's positions makes clear that speakers in fact claim superior knowledge about the subject matter. Still, rejecting recipients' positions with ICH WEIß NICHT is a face-saving way to disagree, because speakers are claiming not to know whether they are right, thus admitting the possibility that the recipients have a point. At the same time, using ICH WEIß NICHT makes it easier for speakers to withdraw from their positions in the future, because they have not overtly claimed secure or superior knowledge.

\section{Conclusion}

This paper has shown that the negative epistemic construction ICH WEIß NICHT is used for a range of different responsive actions. The function of ICH WEIß NICHT in its local context is mostly clarified only after its production, by virtue of the ensuing actions of the speaker. As an exception to this rule, when ICH WEIB NICHT is used as a response to an assertion (an assessment or a rhetorical question), it performs disagreement in this sequential position. Our data show that the other functions of ICH WEIß NICHT are associated with full vs. reduced complementation. However, these associations are not categorical, but only distributional tendencies. After ICH WEIß NICHT with full SVO-complementation,

\footnotetext{
14 "net" is a dialect version of nicht. The speakers come from the region Hesse.
} 
speakers usually do not contribute to the topic anymore or they expand their turn by emphasizing or explaining their lack of knowledge or displaying their reluctance to deal with the topic. When they do not want to deal with the topic, speakers display that they do not want to cooperate in a joint project initiated by the prior speaker. After reduced variants of ICH WEIß NICHT, speakers usually behave cooperatively and continue their turn by contributing to the issue in question. ICH WEIß NICHT operates as a pre-positioned epistemic hedge to guessing: speakers display that they are not sure about the truth of the following statement. When proposals, partial knowledge, or even full answers are provided after ICH WEIß NICHT, it is functioning as a pragmatic marker: speakers display that although they may be sure about the truth of subsequent assertions, they are not considered to be sufficient as answers to the preceding question.

In sum, the following grammatical, turn-constructional, and sequential properties of the local usage environment of ICH WEIß NICHT work to define the local function of ICH WEIß NICHT:

1) full vs. reduced complementation of the verb (see above),

2) type of action in the prior turn to which the ICH WEIß NICHT-turn responds: most instances of ICH WEIß NICHT are used in answers to (epistemic) wh-questions or polar interrogatives. After statements, assessments, and rhetorical questions, ICH WEIß NICHT indexes disagreement with the prior speaker's (pro)position.

3) type of action(s) the same speaker produces after ICH WEIß NICHT: only by virtue of the turncontinuation after ICH WEIß NICHT, and sometimes even only after actions by the same speaker in the ensuing sequence, can the function of ICH WEIB NICHT be definitively understood. Its function is constituted not at once, but emerges incrementally, step by step over the course of the following interactional development, except for the disagreement use.

ICH WEIß NICHT can have a retrospective or a prospective temporal scope. ICH WEIß NICHT with SVOcomplementation typically has retrospective scope over (parts of) the prior turn, because the object pronoun (das or es) is preferentially understood to be anaphoric ('I don't know the answer to question X.'). For the reduced complementation variants of ICH WEIB NICHT, the scope seems to be rather prospective, since in these cases the TCUs after ICH WEIß NICHT are treated as tentative answers to prior questions. In these cases ICH WEIß NICHT may be understood either epistemically ('I don't know if the following proposition $Y$ is true, but $I$ consider it to be a possible answer to question $X^{\prime}$ ) or metapragmatically ('I don't know if the following proposition $\mathrm{Y}$ is sufficient, but it may help to clarify the question $X^{\prime}$ ). 
The meaning of ICH WEIß NICHT seems to range from 'to have no knowledge' (Patterns 1 and 2 and maybe Pattern $3^{15}$ ) through 'to be uncertain about a proposition or about its sufficiency/relevance' (Pattern 4) to 'to disagree with a previously stated (pro)position' (Pattern 5).

With these results, our paper contributes to the study of 'positionally sensitive grammar' (Schegloff, 1996; Thompson et al., 2015) and of the relevance of constructional variants for interactional uses of grammatical constructions in German. It has shown in which sequential environments and for which pragmatic functions different variants of complementation of the negative epistemic mental verb $\mathrm{ICH}$ WEIß NICHT are used.

\section{References}

Aijmer, Karin, 2009. "So er I just sort I dunno I think it's just because...": A corpus study of I don't know and dunno in learners' spoken English. In: Jucker, A. H., Schreier, D., Hundt, M. (Eds.), Corpora: Pragmatics and Discourse, Papers from the 29th International Conference on English Language Research on Computerized Corpora (ICAME 29). Amsterdam, pp. 151-168.

Auer, Peter, Günthner, Susanne, 2005. Die Entstehung von Diskursmarkern im Deutschen - ein Fall von Grammatikalisierung? In: Leuschner, T., Mortelmans, T., de Groodt, S. (Eds.), Grammatikalisierung im Deutschen. Berlin, de Gruyter, pp. 335-362.

Auer, Peter, Lindström, Jan, 2015. Left/right asymmetries and the grammar of pre- vs. postpositioning in German and Swedish talk-in-interaction. Interaction and Linguistic Structures (InLiSt) 56, 1-35.

Beach, Wayne A., Metzger, Terri R., 1997. Claiming insufficient knowledge. Human Communication Research 23 (4), 562-588.

Bilmes, Jack, 1988. The concept of preference in conversation analysis. Language in Society 17, 161181.

Couper-Kuhlen, Elizabeth, Barth-Weingarten, Dagmar, 2011. A system for transcribing talk-ininteraction: GAT 2. Translated and adapted for English by Elizabeth Couper-Kuhlen and Dagmar Barth-Weingarten. Gesprächsforschung 12: 1-51, URL: http://www.gespraechsforschungozs.de/heft2011/px-gat2-englisch.pdf. [last accessed: May 4th 2016]

Diani, Giuliana, 2004. The discourse functions of / don't know in English conversation. In: Aijmer, K., Stenström, A. B. (Eds.), Discourse Patterns in Spoken and Written Corpora. Amsterdam/Philadelphia, John Benjamins, pp. 157-171.

Duden, 2013. 'wissen'. http://www.duden.de/rechtschreibung/wissen. [last accessed: June 9th 2015]

Fraser, Bruce, 1996. Pragmatic markers. Pragmatics 6 (2), 167-190.

Helmer, Henrike, Deppermann, Arnulf, Reineke, Silke, 2017. Antwort, epistemischer Marker oder Widerspruch? Sequenzielle, semantische und pragmatische Eigenschaften von ich weiß nicht. In: Deppermann, A., Proske, N., Zeschel, A. (Eds.), Verben im interaktiven Kontext. Mentale Verben und Bewegungsverben im gesprochenen Deutsch. Tübingen, Narr.

\footnotetext{
15 Pattern 3 might also reveal a rather strategic use of ICH WEIß NICHT.
} 
Helmer, Henrike, Deppermann, Arnulf, 2017. Ich weiß nicht zwischen Assertion und Diskursmarker. Temporale in situ-Interpretation und Kriterien für Diskursmarker. In: Blühdorn, H., Deppermann, A., Helmer, H., Spranz-Fogasy, T. (Eds.), Diskursmarker. Radolfzell, Verlag für Gesprächsforschung.

Heritage, John, Raymond, Geoffrey, 2005. The terms of agreement: Indexing epistemic authority and subordination in talk-in-interaction. Social Psychology Quarterly 68 (1), 15-38.

Imo, Wolfgang, 2007. Construction Grammar und Gesprochene-Sprache-Forschung. Konstruktionen mit zehn matrixsatzfähigen Verben im Gesprochenen Deutsch. Tübingen, Niemeyer.

Kärkkäinen, Elise, 2003. Epistemic Stance in English Conversation: A Description of Its Interactional Functions, with a Focus on / think. Amsterdam/Philadelphia, John Benjamins.

Keevallik, Leelo, 2006. From discourse pattern to epistemic marker: Estonian (ei) tea 'don't know'. Nordic Journal of Linguistics 29 (2), 173-200.

Keevallik, Leelo, 2011. The terms of not knowing. In: Stivers, T., Mondada, L., Steensig, J. (Eds.), The Morality of Knowledge in Conversation. Cambridge, Cambridge University Press, pp. 184-206.

Lindström, Jan, Karlsson, Susanna, in this issue. Tensions in the epistemic domain and claims of noknowledge. A study of Swedish medical interaction.

Maschler, Yael, 2012. Emergent projecting constructions: The case of Hebrew yada ( $k n o w)$. Studies in Language 36 (4), 785-847.

Maschler, Yael, in prep. The emergence of Hebrew loydea/loydat ('I dunno masc/fem') from interaction: Blurring the boundaries between discourse marker, pragmatic marker, and modal particle. In:Sansò, A., Fedriani, C. (Eds.) ,Pragmatic Markers, Discourse Markers and Modal Particles. New Perspectives, Amsterdam/Philadelphia, JohnBenjamins.

Östman, Jan-Ola, 1981. 'You know': A Discourse-Functional Approach. Amsterdam/Philadelphia, John Benjamins.

Pichler, Heike, 2007. Form-function relations in discourse: The case of / don't know. Newcastle Working Papers in Linguistics 13, 174-187.

Pekarek Doehler, Simona, in this issue. Not just an epistemic hedge: French je sais pas 'I don't know' as a resource for sequentially organizing turns and actions.

Pomerantz, Anita, 1984. Agreeing and disagreeing with assessments: Some features of preferred/dispreferred turn shapes. In: Atkinson, J., Heritage, J. (Eds.), Structures of Social Actions. Cambridge, Cambridge University Press, pp. 57-101.

Potter, Jonathan, 1997. Discourse analysis as a way of analysing naturally occurring talk. In: Silverman, D. (Ed.), Qualitative Research: Theory, Method and Practice. London, Sage Publications, pp. 144-160.

Schegloff, Emanuel A., 1996. Turn organization: One intersection of grammar and interaction. In: Ochs, E., Schegloff, E. A., Thompson, S. A. (Eds.), Interaction and Grammar. Cambridge, Cambridge University Press, pp. 52-133.

Scheibman, Joanne, 2000. I dunno: A usage-based account of the phonological reduction of don't in American English conversation. Journal of Pragmatics 32, 105-124. 
Selting, Margret, Auer, Peter, Barth-Weingarten, Dagmar, Bergmann, Jörg, et al., 2009. Gesprächsanalytisches Transkriptionssystem 2 (GAT2). Gesprächsforschung 10: 353-402, URL: http://www.gespraechsforschung-ozs.de/heft2009/px-gat2.pdf. [last accessed: May 4th 2016]

Stivers, Tanya, 2008. Stance, alignment, and affiliation during storytelling: When nodding is a token of affiliation. Research on Language and Social Interaction 41 (1), 31-57.

Stivers, Tanya, Rossano, Federico, 2010. Mobilizing response. Research on Language and Social Interaction 43 (1), 3-31.

Sweetser, Eve, 1990. From etymology to pragmatics. Metaphorical and cultural aspects of semantic structure. Cambridge University Press, Cambridge.

Thompson, Sandra A., 2002. "Object complements" and conversation: Towards a realistic account. Studies in Language 26 (1), 125-164.

Thompson, Sandra A., Fox, Barbara A., Couper-Kuhlen, Elizabeth, 2015. Grammar in Everyday Talk: Building Responsive Actions. Cambridge, Cambridge University Press.

Tsui, Amy B. M., 1991. The pragmatic functions of / don't know. Text 11 (4), 607-622.

Weatherall, Ann, 2011. I don't know as a prepositioned epistemic hedge. Research on Language and Social Interaction 44 (4), 317-337.

\section{Appendix: Selected GAT2-conventions}

Sources: Selting et al. (2009), Couper-Kuhlen and Barth-Weingarten (2011)

\begin{tabular}{|c|c|}
\hline$\left[\begin{array}{ll}{[} & ]\end{array}\right]$ & overlap and simultaneous talk \\
\hline - & latching \\
\hline (.) & micropause (shorter than $0.2 \mathrm{sec}$ ) \\
\hline$(-),(--),(---)$ & pauses of $0.2-0.5,0.5-0.7,0.7-1.0 \mathrm{sec}$ \\
\hline$(2.85)$ & measured pause \\
\hline geht_s & assimilation of words \\
\hline$:,::, \quad:::$ & segmental lengthening, according to duration \\
\hline so $(h) \circ$ & laugh particles within talk \\
\hline haha hehe hihi & laugh syllables \\
\hline ( (laughs)) & description of laughter \\
\hline akZENT & strong, primary stress \\
\hline ak! ZENT! & extra strong stress \\
\hline
\end{tabular}




\begin{tabular}{|c|c|c|}
\hline \multicolumn{2}{|l|}{ akzEnt } & weaker, secondary stress \\
\hline ? & & pitch rising to high at end of intonation phrase \\
\hline ， & & pitch rising to mid at end of intonation phrase \\
\hline- & & level pitch at end of intonation phrase \\
\hline ; & & pitch falling to mid at end of intonation phrase \\
\hline . & & pitch falling to low at end of intonation phrase \\
\hline$\uparrow$ & & jump to higher pitch \\
\hline$<<f>\quad>$ & & forte, loud \\
\hline$<<\mathrm{p}>\quad>$ & & piano, soft \\
\hline$<<\mathrm{pp}>\quad>$ & & pianissimo, very soft \\
\hline$<<\operatorname{dim}>$ & & diminuendo, decreasing loudness \\
\hline$<<a l 1>\quad>$ & & allegro, fast \\
\hline$<<\operatorname{len}>\quad>$ & & lento, slow \\
\hline${ }^{\circ} \mathrm{h},{ }^{\circ} \mathrm{hh},{ }^{\circ} \mathrm{hhh}$ & & inbreath, according to duration \\
\hline h, hh, hhh & & outbreath, according to duration \\
\hline$<<$ creaky voice $>$ & $>$ & commentaries regarding voice qualities with scope \\
\hline$(x \times x \quad x x x)$ & & unintelligible, according to syllables \\
\hline (solche) & & uncertain transcription \\
\hline
\end{tabular}

Henrike Helmer is a researcher at the Pragmatics Department at the Institute for the German Language. Her research focuses on Interactional Linguistics, Conversation Analysis and Construction Grammar. She is currently studying issues of the interactive constitution of meaning.

Silke Reineke is a researcher at the Pragmatics Department at the Institute for the German Language. Her research focuses on Conversation Analysis, Interactional Linguistics and epistemics in interaction. Arnulf Deppermann is head of the Pragmatics department at the Institute for the German Language. $\mathrm{He}$ is studying the linguistic and interactional practices of displaying understanding in interaction and is interested in the coordination of linguistic and other semiotic resources in multimodal interaction. 